\title{
Variance in time morphologies in production and consumption of incense in medieval Japan
}

\author{
Ammann, Vroni
}

\begin{abstract}
Time was variable in medieval Japan, with plural morphologies of time coexisting simultaneously. Not only can they be found in different realms of medieval life, but research on this question suggests even several time conceptions occurred in one and the same symbolic form. This paper aims to support the thesis by examining temporalities inherent in clocks and specifically in incense clocks, and it focuses on the symbolic form of economy for a first delineation of economic time. Incense, closely connected to the religious realm, was used as a medium for measuring time in a rather secular function. While it is an important good in the context of religious life, incense plays the role of a traded good in economic calculations or as a medium for artistic expression as well. A temporal analysis of a set of incense instructions, in its function as a manual for mixing incense as well as an expression of noble scholarship, informs how people measured time and scheduled their life. In contrast to other medieval documents, incense instructions were written without conscious thought towards time; therefore, the analysis here is focused mostly on chronographic and chronopolitical information.
\end{abstract}

DOI: https://doi.org/10.1163/9789004470170_013

Other titles: Chapter 11 Variance in Time Morphologies in Production and Consumption of Incense in Medieval Japan

Posted at the Zurich Open Repository and Archive, University of Zurich

ZORA URL: https://doi.org/10.5167/uzh-208915

Book Section

Accepted Version

Originally published at:

Ammann, Vroni (2021). Variance in time morphologies in production and consumption of incense in medieval Japan. In: Misztal, Arkadiusz; Harris, Paul A; Parker, Jo Alyson. Time in Variance. Leiden: Brill, 195-219.

DOI: https://doi.org/10.1163/9789004470170_013 


\title{
Variance in Time Morphologies in Production and Consumption of Incense in Medieval Japan
}

\section{Vroni Ammann}

\begin{abstract}
Time was variable in medieval Japan, with plural morphologies of time coexisting simultaneously. Not only can they be found in different realms of medieval life, but research on this question suggests even several time conceptions occurred in one and the same symbolic form. This paper aims to support the thesis by examining temporalities inherent in clocks and specifically in incense clocks, and it focuses on the symbolic form of economy for a first delineation of economic time. Incense, closely connected to the religious realm, was used as a medium for measuring time in a rather secular function. While it is an important good in the context of religious life, incense plays the role of a traded good in economic calculations or a medium for artistic expression as well. A temporal analysis of a set of incense instructions, in its function as a manual for mixing incense as well as an expression of noble scholarship, informs about how people measured time and scheduled their life. In contrast to other medieval documents, incense instructions were written without conscious thought towards time; therefore, the analysis here is focused mostly on chronographic and chronopolitical information.
\end{abstract}

\section{Keywords:}


- Incense

- Japan

- Incense clock

- Symbolic forms

- Trade

- $\quad 11^{\text {th }}$ to $15^{\text {th }}$ century

- Time

- Tōdaiji

- Gofushimiin shinkan takimonohō

\section{Introduction}

In this paper I aim to connect economic temporal thinking and incense by means of the incense clock as well as a medieval document serving as an instruction for incense mixtures. First, I will discuss the function of different clocks and their temporality, focusing on incense clocks and showing a more detailed approach with the example of the incense clock used during the spring ceremony of Shunie 修二会 at Tōdaiji Temple 東大寺. ${ }^{1}$ This discussion is

1 東大寺 “Eastern Great Temple“: Buddhist temple complex in Nara, and center of Kegon school of Buddhism. It was founded after a series of disasters and, after several relocations, the imperial court finally settled in Heijōkyō 平城京 (today’s Nara), and it was commissioned by the imperial couple Shōmu 聖武 and Kōmyō 光明. Although it was 
followed by the outline of a developing economy, facilitating the consumption of exotic goods like incense, and highlighting linear temporal thinking required for the planning and scheduling of trade. The analysis is based upon the morphologies of time developed by (2017) and adapted by Raji Steineck (2017), specifically a differentiation of linear, cyclic, and circular time. The analysis of examples drawn from the Gofushimiin shinkan takimonohō 後 伏見院宸翰薰物方 (the incense formulae of the imperial house Go-Fushimi), a document written at the beginning of fourteenth century, will conclude the investigation on incense and its relation to time. I will apply the terminology used by Roland Harweg (2009, 1-59) on how time is measured in a text (chronography) as well as that used by Günter Dux (1989, for example, 49-65) and Eviatar Zerubavel (1976, 88-930) on how time is organized (chronopolicy).

\section{Circular and cyclic time}

In history, points are often made by the formulation of binary oppositions, like the famous good-bad, West-East or, in terms of temporality, linearity and circularity. These two temporalities then are singled out and unite under their wing several other time morphologies. Griffiths $(2005,57)$, for example, mentions deviant morphologies, but he does not take them into account in the following discussion. ${ }^{3}$ Maki, like others, does not differentiate between

founded earlier (738), Tōdaiji was not opened officially until 752, celebrated with the eyeopening ceremony for the large bronze statue Buddha Vairocana (Tsutsui 2018, 7).

${ }^{3}$ Griffiths determines the time scape of most societies through history to be cyclical and cites examples of the Hopi image of time as self-contained wheel, of time moving in 
circular and cyclic time, but still he tries to contrast 4 different morphologies in one diagram. The two reversible time morphologies in his work are called hanpukutekina jikan 反復的な時 間 (oscillating time) and enkantekina jikan 円環的な時間 (circular time) (Maki 2017, 195; Steineck 201, 24-26). Both forms are entirely reversible and therefore highly abstract, as such a world would consist of no memory, no development. and no history. Cyclic time, however, a morphology not discussed in either authors' works, contains a linear vector, and one could imagine this as the more adaptable morphology to everyday life, picturing time to flow in a spiral, circular when seen from above, oscillating between two points translated on the vector of time when seen from the side. Hence, I propose to use the concepts of oscillating and circular time in an abstract context. While a worldview like this is imaginable, the sources we are using suggest consciousness about differences between last years' first month and the current one. This differentiation would not be possible in a circularly moving flow of time. Circular time sets development repeatedly to zero, and a progression only is visible in the simple counting of numbers (examples here may be the living through thousands of lives in Buddhist belief, or praying a high and abstract number of prayers for the redemption of all during the spring festival shunie). Circular time rather belongs into abstract and tautological thought of the religious symbolic form (Cassirer 2010), while cyclic time with even small changes over the months or years is close to the concrete human experience, even more so than the modern linear understanding of time. Griffiths never bothers to speak of linear or cyclic time schemes, but he calls the time of modern Euro-American culture dead time, which is disembodied from the life of the people, "the moment struck dumb by the striking clock, the deadening character of routines, schedules and endlessly counted and accounted time"

cycles, and of the ancient Greeks, where time itself was imagined as a circle. All these morphologies combined to something not moving in a straight line are then positioned against linear time, a "rare and recent idea." 
(2016, 54-55). This dead time is contrasted with the living time of indigenous peoples, measured by tree calendars and insect and bird clocks. ${ }^{4}$ Such a clock only works with the expectation of ever repeating events, working as the "alarm" which sets off action. The exact hour in a countable timeline is of little importance and does not support these actions and their outcome in a helpful way.

While such natural clocks are not considered in the following part, I would like to stress their usefulness as agents of the environment, strongly connected to the task for which they are used. Other than "living clocks," the following devices usually do not take into account the sensible ecosystem with its multitude of factors, but only rely on a few, or even one (water, sunlight, burning incense). Clocks, in this sense, are simplifications of processes, in their development moving away from their origin and dropping their connection to the measured element. Digital clocks from our modern life show this tendency in extremis, even shedding representational material and expression, to tick away time in a sequence of abstract numbers measured in the invisible world of an atomic energy-level change. The clocks analyzed here are somewhere in between and allow for an interpretation of the clock users' view on time in a macroscopic environment.

\section{Clocks and Temporality}

Besides observing the position of the stars or our sun, individuals in medieval Japan were using several different timekeeping devices, each one specified through their function for certain phases of day (sunlight necessary for a sundial) or year (temperatures over freezing

\footnotetext{
${ }^{4}$ Many thanks to the anonymous reviewer, who suggested Griffith's article.
} 
point, as the sometimes huge clepsydra often were built outside), some even relatively independent from the environment and weather. Also, a clock allowed for more accuracy than approximations like "let us finish work at sundown . A court official probably needed to know about the hour of a specific day for planning a meeting of high-ranking nobility or for the organization of an imperial ritual conducted by a large part of the court personnel. It was necessary for such a person to follow a schedule, to write a structured diary, and to wake up by the sound of a bell in the early morning to manage the work of dozens of individuals into a functioning organism. Clocks and diaries therefore played an important role in the management and organization of the imperial court, and certainly the same was true in important Buddhist temples and other centers of power, assembling crowds of different social strata in one place.

Sundials have been used very early in human history and were mentioned in Greek and Babylonian documents well before the beginning of the Christian calendar. Bedini (1994, 8)) cites the Zhōuli 周禮 (Rites of Zhou, a Confucian classic supposedly composed in the first century CE), mentioning an "installation of a straight pole to observe its shadow," followed by a reference to the Zhōubì suànjīng 周䯏算經 (Arithmetical classic regarding the Zhou gnomon), supposedly composed in the first century BCE and describing the use of a gnomon during the time of the Western Zhou dynasty (eleventh century-770 BCE), hence placing the appearance of the sundial in East Asia into the millennium before Christ. Certainly the intricacies of later sundials developed over time, but the key time morphologies remained the same. Sundials measure time in an absolute way, which means that they show the hour during the course of a day and acknowledge the changing length of days by the shift of the shadows' position over the year, but without relating the measured moments to the temporal position of the observer in a linear flow of time of a larger time scale. Even if a sundial is using the relative movement of earth and sun for its operation, it seems, in itself, motionless. This 
impression stems from the fact that a sundial is measuring time cyclically, reflecting the same conditions of the annual cycle one year after the other, bound to the changes the solar system may undergo over time.

For the measurement of time without starlight, new developments were necessary. The water clock, or clepsydra, measures time periods by means of successive water tanks, and it was used in Egypt and Babylonia “centuries before early Shang period" (Bedini 1994, 10), which places its appearance in a time before 1800 BCE. Bedini (1994, 10-11). lists several sources that describe the use of a simple form of water clock in early China at least from the year 2356 BCE. The Nihon shoki 日本書紀 (Chronicles of Japan, 720) mentions the first water clock to be introduced to Japan in the year 660 by the crown prince, the later Tenji Tennō (626-672). ${ }^{5}$ The hours were announced by drums or bells and with this introduced abstract time to the people. Their rhythm of life now was regulated by an external source. ${ }^{6}$ As with sundials, clepsydrae were improved and extended over the centuries, but the principle remained the same: water flows steadily from one bowl into the next, while the water surface or a floater marks the elapsed time on a scale on the inside of the tank. It measures duration, as opposed to the sundial, which measures and shows points in time. This means that, if one marks the starting and ending point of a given length of time, the visual representation on the incense clock always will be the same, as the ember wanders over the plane. This is not the case with sundial, as the length of the fractions of time on the dial change constantly, depending on the sun's position during the year. The measurement of duration is absolute,

${ }^{5}$ Original source: Nihon shoki, scroll no. 26. https://zh.wikisource.org/wiki/日本書 紀/卷第廿六. Accessed 10 Oct, 2019, 19:13.

${ }^{6}$ On the announcement of time, see Hashimoto 1978:,99-102; on abstract time see Maki 2017, 124. 
and it cannot be related to external moments in time, with the exception of using additional devices that count the time segments. In this function and with a sufficient supply of water, the water clock in principle is measuring time in a circular, unchanging manner. Other clock types like the lamp clock or the sand clock operate according to the same pattern, measuring duration instead of points in time, allowing for the measurement of daily tasks and scheduling rather than connecting the observers' time to specific moments in history.

In medieval Japan, a clocks' function was not reduced to measuring time. The command over time was used by the elite as a tool of power (Griffiths 2005, 60), and all types of clocks subsequently found their way to the Japanese centers of power. They also were used as gifts to the wealthy: Oda Nobunaga, for example, a key figure in the power structure of feudal sixteenth century Japan, was well known to be interested in foreign technology and collecting mechanical clocks. Clocks in this context were normatively used for showcasing power rather than measuring time. ${ }^{7}$

Clocks have been used for different things than timekeeping, a fact that alerts us to the difference of clock and time altogether. Lived time, as Canales $(2016,117)$ explains, citing the philosophers Bergson, Husserl, and Heidegger, differs by the concept of "personal equation" from clock time. It is the difference between time assessed by a person and time marked by a machine (or in our context, by a device). This concept separates "world time" and "lived time" and makes the differences between the nature of the world and the world conceived by human consciousness tangible (Canales 2016, 117) The incense clock, the subject of the next chapter, specifically measures time in a context, whereas time personally

${ }^{7}$ Drawn from Angelika Koch's presentation “Diplomatic Devices: Clocks and Clashing Time(s) in late $16^{\text {th }}$ and early $17^{\text {th }}$ Century Japan," given at the conference "Time in Variance“ conference. Also see: Angelika Koch (2020), 80-82. 
experienced may significantly diverge from measured time, for example, during meditation, or while reading and writing.

\section{Incense Clocks}

The incense clock has rarely been described in Japanese documents over the centuries and has received much less attention than other timekeepers. It is possible to find incense clocks in museums nowadays, but these exhibits usually were built in Edo period or later. It is an object one finds regularly in the personal belongings of monks, still in use for measuring the monks' time of meditation and prayer. Other than the Tōdaiji incense clock for example, these clocks usually are called jōkōban 常香盤, ${ }^{8}$ and they take a distinctive form different from other incense clocks. Observed from the side, they look like a heavy dumbbell, with a square surface looked upon from above. On the lower end, they are equipped with one or two small drawers, which contain the utensils for incense preparation. The upper container is protected by an elaborate latticed lid and is intended to be filled with ash. By using the hollows of a mold, a pattern from powdered incense is formed and pressed together. This allows the user to burn the incense gradually, similar to burning an incense stick (see figure 1, photograph). Plaques usually tag the points of passing time by displaying the 12 characters of the Chinese zodiac. Other than the equinoctial 24 hours of modern timekeepers, the system adopted from China after the Taika Reforms (645-650 CE) consists of 12 double hours of the circadian period (one day and one night), represented by the names of the 12 earthly branches

${ }^{8}$ Incense seal burner. $J \bar{o} k \bar{o}$ is synonymous for hyakkokukō 百刻香 or kōin 香印, all expressions describing a pattern made from powdered incense and pressed in from on an ash bed, used for the measurement of time; see Jinbo 2004, 366, 412. 
for differentiation and characterization. Even if the hours first were equinoctial (or equal), there is evidence that religious use increasingly propagated temporal hours with changing length during the year from the tenth century on (Steger and Steineck 2017, 12-13; Hashimoto 1978, 25-27; Miyake 2010, 168 ). Temporal daytime hours at summer solstice, for example, measure about 144 minutes, while at winter solstice their duration shortens to 95 minutes. The plaques on the surface of the incense clock therefore were not installed permanently in order to allow for adjustment.
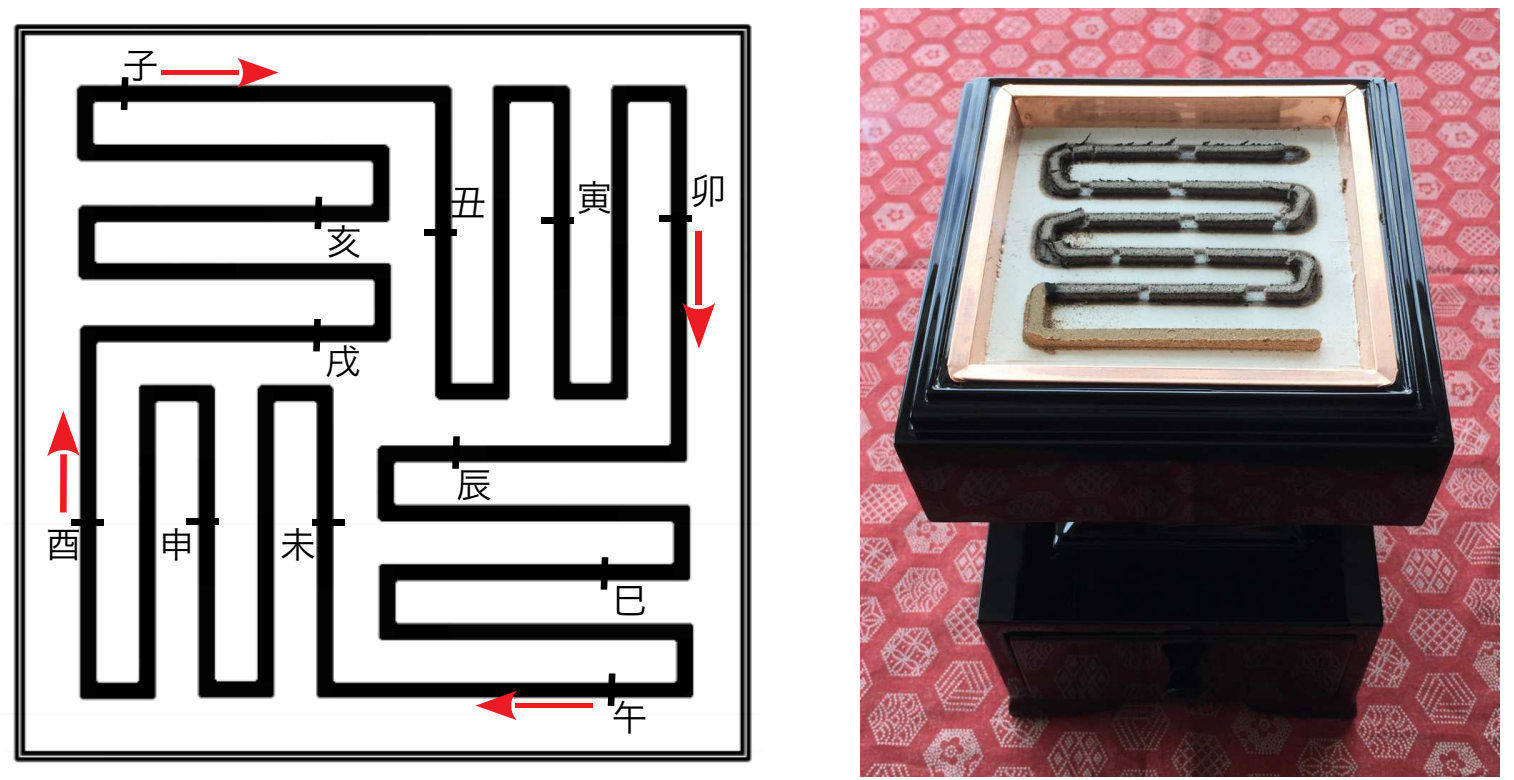

Figure 1

The schematic representation of a common pattern (the Buddhist swastika) used for incense clocks and reference plaques manually positioned to indicate the change of the hour; photograph taken June 15, 2019 by the author of her own incense clock.

The size of the clock and, accordingly, the size of the incense seal on top as well as the pattern itself, define the measurable time; it ranges from a few hours to a few days. The incense clocks still available in todays' specialized shops, for example, burn for about three 
modern hours; the jikōban 時香盤 (time incense burner or incense clock) of Tōdaiji on the other hand lasts for about a day. Morphologically, the clock reflects a segmented cyclic understanding of time with a consciousness regarding the flow of time and its changes in one year, divisible in repeated segments. The linearity inherent in cyclic thought shows the consideration of annual events, but its focal function never exceeds the cycle of a year. The huge incense coils that one may find in Chinese temples, burning for several months due to their impressive size, serve to exude fragrance on a long-time basis rather than measure time for the sake of linear continuation.

\section{The Incense Clock of Tōdaiji Nigatsudō}

The jikōban of Tōdaiji stands close to the central sanctum in the Naijin 内陣 (inner chamber) of the Nigatsudō 二月堂 (hall of the second month), its name already indicative of the important annual spring ritual of the Shunie. The ritual had been held during the second month of the Chinese lunisolar calendar, but nowadays it takes place between the $1^{\text {st }}$ and the $14^{\text {th }}$ of March. First performed by the monk Jitchū 実忠 (?-824) ${ }^{9}$ as one of the most important rituals of Tōdaiji, Shunie was held annually without interruption from $752 \mathrm{CE}$. It was conducted so that one could repent one's transgressions before Buddha ( $k e k a$ 悔過), but nowadays visitors are mainly attracted by the spectacular big torches, scattering their burning embers from the porch of the Nigatsudō over the crowd at 7 p.m. every evening, as well as the

\footnotetext{
${ }^{9}$ Buddhist monk of Kegon school and pupil of Roben 良弁 $(689-773$, founder of
} Tōdaiji). 
drawing of water ceremony (Omizutori お水取り) performed at the climax of the ritual at day 12 (Nara National Museum 2016, 4). Still, the eleven monks of the Rengyōshū 練行衆 (those who practice continuously) follow a rigid regime during these days, and for their work they are highly revered by the crowd. ${ }^{10}$ Each of these secluded men fulfils the specific tasks at defined moments during the day (Satō 2009, 65-70). The routine of the Shunie ceremonial can be gleaned from the Tōdaiji shunie gyōji shidai jikokubyō 修二会行事次第時刻表 (festival program of the Tōdaiji shunie) (Horiike 2008, 13) ${ }^{11}$, and it is described in a task-oriented table by Satō $(2009,83) .{ }^{12}$ These tasks have to be performed during specific time slots, the rokuji 六時 or "six Buddhist hours," 13 measured by the jikōban, which was used exclusively for this reason, as the table below indicates:

\begin{tabular}{|l|l|l|l|l|}
\hline Buddhist hour & Transliteration & Translation & Zodiacal system & Modern time \\
\hline 日中 (中時) & nitch $\bar{u}$ & $\begin{array}{l}\text { noon, mid-day } \\
\text { (also daytime) }\end{array}$ & hour of the horse & $\begin{array}{l}11 \text { am to 1 pm; } \\
\text { "during day" }\end{array}$ \\
\hline
\end{tabular}

10 The number of monks fluctuated during the centuries from only a few to about 20 men. Nowadays each of the four appointees 四職 is supported by an aide (only the Dōtsukasa, the head of the hall as grand marshal of ceremonies depends on two aides), as they lead the other seven members of the Rengyōshū through complex tasks.

${ }^{11}$ Further extensive information regarding the ceremony from December 16, when the election for the members of the Rengyōshū is announced, until March 18, when the eternal lamp will be extinguished, can be found on pages 98 to 161 .

12 The pages following contain a schedule of the days preceding the main ceremonial phase.

${ }^{13}$ Dejitaru Daijirin デジタル大辞林. 2012. Second edition. “六時“. Accessed on www.japanknowledge.com 28 August, 2019, 12:44. 


\begin{tabular}{|l|l|l|l|l|}
\hline 日没 (中時) & nichimotsu & sunset & $\begin{array}{l}\text { hour of the } \\
\text { rooster }\end{array}$ & $5 \mathrm{pm}$ to $7 \mathrm{pm}$ \\
\hline 初夜 (大時) & shoya & nightfall & hour of the dog & 7 to $9 \mathrm{pm}$ \\
\hline 半夜 (小時) & han'ya & $\begin{array}{l}\text { or chūya 中 } \\
\text { 夜: midnight } \\
\text { (also night- } \\
\text { time) }\end{array}$ & hour of the mouse & $\begin{array}{l}11 \mathrm{pm} \text { to } 1 \mathrm{am;} \\
\text { "during night" }\end{array}$ \\
\hline 後夜 (大時) & goya & early hours & hour of the tiger & 3 to $5 \mathrm{am}$ \\
\hline 晨朝 (小時) & jinjō & sunrise & hour of the rabbit & 5 to 7 am \\
\hline
\end{tabular}

The six hours are distinguished into three groups of "big," "medium," and "small hours." These specifications do not indicate their length, but they mark their importance. The two "big hours," shoya and goya, therefore both demand main repentance prayers with the most repetitions, while the prayers scheduled for "small" and "medium hours" are short or their count of repetition is reduced, but admittedly these prayers can be finished in the already starting hour following the big ones (Satō 2009, 95-96). In contrast to the present Western system of measuring the hour in a linear progression from moment to moment, the hours in the double-hour system are measured in durations. This task-oriented approach to scheduling a busy day corresponds to the importance of the Buddhist rites: monks rather have to fulfil these tasks than stick to a specific starting and ending point in their daily schedule; also it allows for a certain flexibility regarding unforeseen interferences or personal speed.

The incense clock standing in Nigatsudō dates back to early Edo period, when the hall was destroyed in a fire and reconstructed in 1667 (see figure 2). Its shape has been the same for all the clocks preceding this one: two lacquered wooden boxes, one above the other, one filled with ash, the other with instruments, standing in front of the inner sanctum of the hall of 
the second month. ${ }^{15}$ Its dimensions are about $35 \mathrm{~cm}$ in width and depth, and both boxes add up to about $16 \mathrm{~cm}$ in height. On the surface of the flat-pressed ash. one can observe an accurate $\mathrm{w}$-shaped form out of powdered incense, with six plaques demarking the six Buddhist hours.

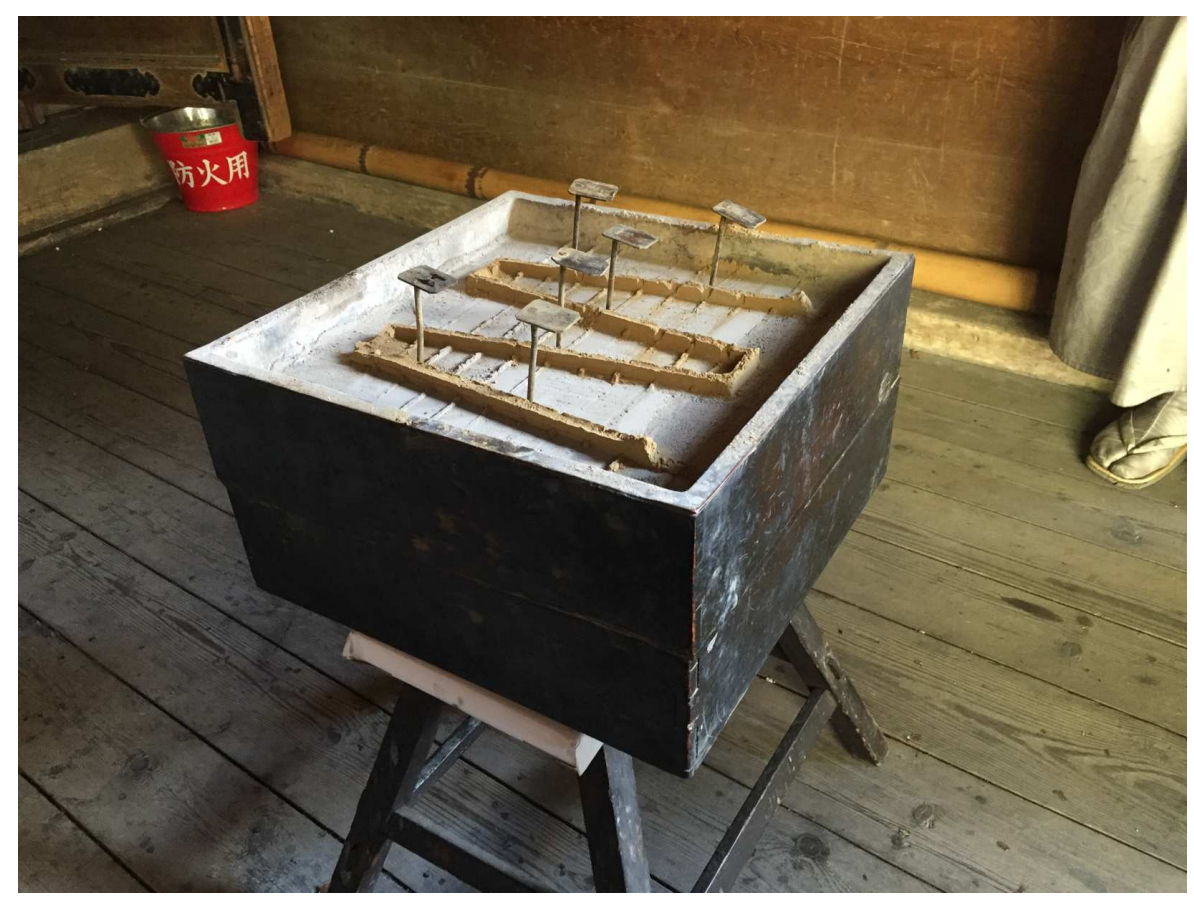

Figure 2

Tōdaiji jikōban. Photograph taken March 13, 2019 by the author.

The responsibility for the handling of the incense clock lies with the Minami no Shū no Ichi 南衆之一 (head of the southern group), a member of the Rengyōshū. Available research literature holds that the incense clock of the Nigatsudō was used as time measurement device for ensuring the accuracy of the schedule without the sun in sight line (see, for example

${ }^{15}$ Ueno Shūshin, interview during a research stay in Nara in March, 2019. 
Bedini 1994, 166), but during my visit I was informed that now a modern wristwatch is used for the timing of the procedure.

But why has incense been used for measuring time in the first place? This question obtains significance even the more when one is standing in front of the hall, where no fragrances can be discerned anymore in the fragrant air of the festival. The amount of incense burners in the inner sanctum of Nigatsudō alone - Satō depicts nine incense burners in her layout plan $(2009,78)$ - as well as the huge bowl for visitors' incense offerings in front of the western opening fill the air with strong odors. This overwhelming mixture of fragrances coming from sources other than the incense clock suggests, that time has not been measured olfactorily but visually by one watching the incense clock's ember drawing closer to the next plaque. The casual manner in regard to the nonexistence of a recipe for incense powder equally suggests that the use of incense in this context is of a rather symbolic nature. Therefore, the reasons for using incense at all remain in the realm of esoteric Buddhism and pragmatism: incense arrived in Japan together with Buddhism and is an essential component of memorial services. ${ }^{16}$ The Lotus sutra for example declares in a passage that a person holding a Buddhist memorial service and using objects like hana 華 (flowers), $k \bar{o}$ 香 (incense), yōraku 珼珞 (personal ornament), dōban 憧幡 (hanging banner), sōgai 繒蓋 (silk canopy), kōyu 香油 (incense oil) or sotō 蘇燈 (butter lamp), will be the source of countless and boundless benefits for others (Matsubara 2012, 16.) ${ }^{17}$ It seems only logical that monks combined the symbolic power of incense with the convenient burning attributes and used it in

${ }^{16}$ Ariga goes as far as to say, that incense is indispensable for Buddhist services $(1995,8)$.

${ }^{17}$ Original source Myōhōrengekyō 妙法蓮華經: http://www.amtb.org.tw/pdf/0801gcbeta.pdf, page 88. Accessed 10 Oct, 2019, 19:05. 
the already known form of a time measurement device. Incense clocks usually being artful objects, the Tōdaiji jikōban is an inornate, well-worn black box, standing in the right corner of the Naijin, easily carried around if required, which indicates as well a pragmatic approach rather than one of enjoying incense in a refined and tasteful way, such as a noble or a monk might do in a different context. Other than this special timekeeper, incense clocks have been used in the palace, government offices, Buddhist temples, or scholars' studies mainly for measuring the time of meditation or learning in a stimulating environment, and while incense was used as a medium for measuring time, incense materials also have been used for their agreeable fragrance and for medical purposes. The reference for incense ( $k \bar{o}$ 香) in old sources often is inseparably connected to the reference of drugs or medicine (yaku 薬), incense ingredients in some cases not only being one but also the other. These versatile properties converted incense and incense materials into sought-after commodities.

\section{Temporal aspect of incense as a commercial commodity}

In this chapter, I will follow the trading routes of three important materials used for incense. The long-term character of international trade with mainly durable goods plays a role in the adoption of a more linear understanding of time and triggers society to see time as a commodity itself.

Historical trade with goods like incense usually is described in a very general way, and it is difficult to find information on specific aromatic ingredients, let alone any declarations on market volume, amounts or traders. Also, documents on incense clocks specifically are rare. However, documents like the Gofushimiin shinkan takimonohō, or the Kunjū ruishō 董 
集類抄 (a type selection of collected works about incense) ${ }^{18}$ provide a general overview of different ingredients and instructions on how they should be mixed and used in a detailed, almost fastidious way. Concentrating on neriko 練香 or kneaded incense, these texts were portrayed as the ultimate instruction for the enjoyment of incense, written for a select group of distinguished and refined people. It is not coincidental that the authorship of the Gofushimiin shinkan takimonohō is attributed to a Japanese emperor. Incense texts often were conveyed in secret from generation to generation, as "profound and secret teachings" of certain families (Go-Fushimi Tennō 1971, 19/564). The makkō 抹香 (incense powder) for the Tōdaiji jikōban for example is not mentioned in writings, and instructions on how to handle the clock were orally transmitted from monk to monk without an instructive document whatsoever. In regard to the incense clock powder, the consensus seems to be that a person may choose the ingredients freely while mixing incense for his or her personal device. Still, one online source provides information regarding Buddhist and Shintoist custom ingredients: both use jinkō 沈 香 (aloeswood), byakudan 白檀 (sandalwood) and chōji 丁子 (clove). Buddhist monks add shikimi no ki シキミの木 (Japanese star anise), while in the Shinto context one adds nemu no $k i$ ネムノキ (Persian silk tree) to the select ingredients above..$^{20}$ The blog entry further

${ }^{18}$ Written and compiled by Fujiwara Norikane 藤原範兼 (1107-1165) from 1163 to 1165 .

20 The art dealer Iwano Art gives additional information about rare or unfamiliar antiquities and art pieces in a continuous blog. Such blog entries may spark an interest in goods Iwano Art at times has on offer. The category here reads "Useful information regarding antiquities and art pieces" and contains an article titled "Has the time really been measured by fragrance? Let's try and look for a jōkōban!", a short text with a few unreferenced pictures highlighting incense clocks (Iwano Bijutsu Kabushiki Gaisha いわの 
instructs one to use these ingredients as one likes, and it omits quantities. By personal observation of the jikōban incense seal of Tōdaiji, I deduced from its warm yellow color and fragrance that the powder mainly contained sandalwood.

Incense ingredients had to be imported to Japan, as only Japanese star anise and Persian silk tree grow on Japanese territory. Aloeswood was the main ingredient even before the shift from Okō 御香 to Kōdō 香道 in the sixteenth century. The differences between these two practices are considerable, and each required a different set of materials for the enjoyment of incense: Okō practitioners produced singular mixtures of incense and blended unique compositions by using a choice out of about 60 different kinds of incense ingredients, while Kōdō contest participants were to distinguish different qualities of aloeswood during the famous and refined incense contests in Edo period Japan (Hayakawa 2007, 9). Aloeswood is a resin-saturated wood of the family of Aquilaria trees, resinous as the result of an infection with fungus. The quality of aloeswood depends on factors like the species of tree, the geographic origin, the part of a tree, the incubation period, as well as the harvesting method.

Aloeswood first was found on beaches in considerable amounts, as the heavy and durable pieces of wood were washed ashore over the centuries. Singularly famous pieces of aloeswood with unique and recognizable fragrances were known as meikō 名香, adorned with a distinctive name mentioned through history. As the story goes, the famous meikō Ranjatai 蘭奢待 ${ }^{21}$ was chosen as a present for empress Suiko 推古 (554-628) in the sixth century, as

美術株式会社). https://iwano.biz/column/kotto/kotto_method/0331-kohdokei-new.html. Accessed 6 June, 2019, 13:47. I don't see the connection between the incense ingredients and the art.

${ }^{21}$ The characters of the name contain the characters of Tōdaiji (東大寺), insinuating the close bond of this relic and the temple. The large piece of aloeswood measures $156 \mathrm{~cm}$ 
fishermen noticed an aromatic fragrance when they were burning driftwood for warmth. ${ }^{22} \mathrm{~A}$ moderate request for the fragrant wood developed, and when findings of aloeswood on the beach became scarce, Japanese consumers depended on the import of fresher material harvested directly from the plant. As trees from the Aquilaria family only grow in tropic areas, these long trading routes have to be considered an important factor regarding the acquisition of incense ingredients. Cultivation of aloeswood only started very recently, and, in contrast to agrarian incense ingredients, the seasonality of produce therefore did not impact on the availability. The increasing scarcity of collected wood however, the slow and rare development of infected wood, and the specific knowledge necessary for acquiring freshly developed aloeswood from living trees certainly led to more demand than traders were able to supply.

Different qualities of aloeswood were imported from different countries: high quality from Cambodia, medium quality from South Vietnam, and lower quality from the Middle East, South Asia, and the island of Hainan, China (Minagawa 2014, 126-7). Sandalwood, an aromatic yellow wood growing in tropical rain forests, was used not only for woodcarving,

in length and weights $11.6 \mathrm{~kg}$; amongst many other considerably sized aloeswood pieces, it was stored (and still is) in the Shōsōin repository of Tōdaiji (Shōsōinhōko 正倉院宝庫) since the middle of the eighth century. Several famous leaders, like Ashikaga Yoshimasa (1435-90), Oda Nobunaga (1534-82) and the emperor Meiji (1852-1912) are said to have cut pieces from Ranjatai. Information derived from the Shōsōin homepage: http://shosoin.kunaicho.go.jp/ja-JP/Treasure?id=0000012162. Accessed 10 August, 2019, $15: 10$.

${ }^{22}$ Original source Nihon shoki, scroll no. 22. https://zh.wikisource.org/wiki/日本書 紀/卷第廿二. Accessed 3 Oct, 2019, 18:40. 
incense, and incense oil, but also as zukō 塗香 (rubbing incense), a form of perfume in powdered form, used for the cleansing and odorizing of the body. Sandalwood was imported from India (Jinbo 2004, 411-12). Clove grew exclusively on the islands of the Moluccas in Indonesia until the eighteenth century, when it was successfully cultivated on the Zanzibar archipelago in Africa (Jinbo 2004, 388).

Incense and drugs originating from India, Persia, and Southeast Asia irregularly reached Guangzhou via sea and land travel on the silk road routes from the eighth century on; other ports were Quanzhou and Yangzhou (Matsubara, 2012: 19). Minagawa mentions the province of Hoan Chau (today Xu Nghe) in Vietnam as another place of trade for aloeswood but does not elaborate on the nature of the trade or the location of a port $(2014,127)$. The port of entry in Japan then was Dazaifu in Northern Kyūshū, a port in Western Japan not only closer to China and Korea by distance but also sociologically, compared to the capital cities in central and Eastern Japan. ${ }^{23}$ With the beginning of the Heian period (794-1185), trade between Tang China (618-907) and Japan increased, and the Dazaifu Kōrokan 太宰府鴻臚 館, a Japanese branch office for the reception of Chinese traders, was established. The institution was subsequently also used by Song-Chinese traders (960-1279). When Yuan China (1279-1368) came to power, offices for overseas trade were established—for example the office in Quanzhou in 1277. A trading network developed between these offices and the East coast of India through Southeast Asia (Matsubara 2012, 29-45). Even if this development

${ }^{23}$ Amino Yoshihiko was the first historian to put peripheral regions, as well as the sea between the nations' territories, into the center of trading maps, emphasizing the importance of unregulated sea routes and ports regarding trading connections to other countries. For further reading on the subject, see, for example, "Rethinking Japanese History“ (Amino 2012). 
facilitated the access to incense material considerably and channeled the trade volume of rare material to eager and solvent consumers in Japan, the travel routes for incense ingredients still were very long and dependent on the seasons and good weather. These factors influenced heavily on schedules and deals between traders and consumers, a certain flexibility and patience was asked from all trading participants. This time-consuming aspect of rare exotics and non-domestic trade needs to be taken into consideration regarding availability at certain points of time (e.g. annual ceremonies, funerals), price, and further processing of incense materials.

While in the eighth century the "chief-handlers" of commerce most likely were lowerranking bureaucrats (Farris 1998, 327) in a "multi-centered" economy with a multiplicity of official and unofficial markets (Farris, 1998: 313), a hierarchy in terms of first access to goods developed. The most important temples were prime consumers and therefore first buyers not only because of their sufficient funds, but also because Tōdaiji, for example, served as the organizational institution operating the transactions with the traders at the port. Tōdaiji, like other temples, offered a secure space for a marketplace close to the temple where traders avoided the taxes of other authorities (Segal 2011, 79). This development again shortened the time for incense material to arrive at its destination, at least for Tōdaiji as the consumer. From the thirteenth century or earlier, Buddhist monks started to serve as money market agents in their function of collecting monetary donations, while at the same time local markets became the most important sites for the use of cash money in the countryside (Segal 2011, 67-8). This also applies to the Takimonouri 薰物売り or incense seller, a profession shown in a beautifully illustrated scroll from 1500, the Shichijūichiban shokunin utaawase 七 十一番職人歌合 (Poetry contest with the subject of artisans on 71 panels). Every panel, divided by a short paragraph, includes two professions with a poem each. The female incenseseller on panel number 60 is sitting next to the drug-seller on the floor, frozen in the act of 
measuring incense. The poem reads: "It is interesting to observe / how in the humid evening air / countless fragrances are prepared." 24 The accompanying passage tells us about people enjoying a moonlit evening and hearing the incense mortar sounding through the noise of the voices, even if nothing is sold anymore. Unfortunately, it is not possible to deduce whether the incense-seller is a travelling merchant or if she comes to sell at a stall, both ways of selling common in medieval Japan. We therefore cannot extract more information from this scroll about how incense was sold exactly.

A travelling merchant was able to quickly move across the political borders between the provinces, independent of the regulations of Kamakura or Kyoto appointees (Segal 2011, 83). This liberty and swiftness of trade must have applied to a travelling incense-seller as well, shortening the time again for incense to arrive. The description of lengthy travels and the troublesome acquirement of incense material, though abbreviated over the centuries' developments of economy, still may show how consumers of exotics had to plan their purchases if they wanted to produce incense and show off their abilities at scheduled incense contests. Linear time is inherent in economic considerations, and an awareness of linear time is a crucial requirement for the success of any market agent: consciousness of developments from the past into the future, planning for the achievement of future aims, scheduling of transactions with the aim of profit, or the situational adaption in case of shortage or excessall these examples bear traits of a linear understanding of time and cannot function in a circular concept of time. Circular time makes little sense in economic contemplations, where repetition without progress means stagnation and failure, while cyclic time allows at least for some progress and development in a limited sense, compared to strictly linear time.

\footnotetext{
${ }^{24}$ Original: 六十番 薰物売（たきものうり）「随分此香ども/選り整へたれば この夕暮のしめりにおもしろき」(Iwasaki 1993, 122). Own translation.
} 
Linear time however has not been constituted solely by the arrival of a market economy; it always has been part of a cyclic understanding of time. While other concepts lost their importance in this increasingly economic environment, the concept of linear time grew in popularity. Still, all the other temporal concepts continued to play their role in other areas, coexisting and intermingling with newer and more advantageous concepts in regard of socioeconomic developments. The concept of symbolic forms creating bubbles of different temporalities helps us to understand the possibility of simultaneously existing temporal morphologies, as for example linear time has much less impact in religious or artistic realms.

A supporting perspective on the increasing importance of a linear morphology of time is the close link of economic thinking to the incipient reification of time during the institutionalization of trade with foreign countries. This was effected by the installation of traders' offices and the arrangements for a regulated market volume and content. With the exchange of commodities and later the use of money in growing civilizations and an augmented and differentiated production, time started to be a factor regarding the scheduling of processing material into end products. This link is not only intuitively perceptible, but also factual, as Maki explains: Compared to the concrete time of earlier non-monetary societies, time now is measured as well as exchanged with material, detached of all personal relations. It is homogenized as a resource, which can be earned, wasted, saved, and so on. This process disregards personal life, where time certainly is qualitatively differentiated and heterogeneous. This shift from quality to quantity is not limited to time but also refers to material. In non-monetary societies personal needs restrict quantity to a certain degree and emphasize quality, but in a monetary economy the focus lies on quantitative profit, where limits are non-existent (Maki 2017, 298-303). This argument highlights the process of changing time regimes, a process mirroring the changes of a societies' experience. Different time morphologies lose their relevance in some realms of life but not in others; they even may gain in importance. Especially in times of change, this transformation is accentuated by 
conflicts in all areas, for example shown during the development of night work and the resulting higher wages during night shifts, as work during this time impacts on the well-being and private life of a worker.

Incense not only measures time, but it is also part of a market economy dictated by schedules, as well as the treating of time as an asset, and we can expect documents about incense to mirror the variance of coexisting time concepts in their respective realms, as I discuss below.

\section{Incense Instruction}

This paragraph investigates the variance of time by means of text analysis, focusing on the symbolic form of economics. Other symbolic forms like religion, art or administration, in which incense certainly plays an important role, will be mentioned but not tracked further for the sake of clarity. For analysis I turn to the incense instruction Gofushimiin shinkan takimonohō written or commissioned by Go-Fushimi Tennō 後伏見 (1288-1336) in the early fourteenth century. Texts like the Gofushimiin shinkan takimonohō, usually called kōdōsho serve to educate the reader regarding the correct attitude towards the production and consumption of incense, and provide information about the origin of incense consumption and about the contemporary approach. The Gofushimiin shinkan takimonohō contains the author's opinions and detailed instructions on how to mix fragrances in different ways, and it can be divided structurally into three different text types: commentary, formulae with the mixing ratio, and instruction. The commentaries are descriptive and explain the reason for this document, focusing on the connection of certain fragrances and seasons, as well as on the 
bond between incense and Buddhism. The formulae usually are offset by title and indention, as well as visually by gaps between the incense ingredients and their quantity. The text is structured in a peculiar way, as first the author comments on incense in general and then provides a secret formula for kurobo, one of the six fragrances. ${ }^{25}$ In between this formula and the other fragrances' formulae, a large section is dedicated to instructions for preparing the incense ingredients and the composite additives. This part then is followed by a general choice of recipes for each of the six fragrances.

Chronographically, the Gofushimiin shinkan takimonohō is absolute, relative to our present only implicitly via our knowledge of the reign of Go-Fushimi Tennō (1298 to 1301), but without chronometric information regarding the composition date. This disconnection fits its function as a manual, as recipes are generally valid independent of their publication date or the time of the user. Units may be temporally viewed regarding their application in the respective present, necessitating translation to more modern units and containing information about the time of composition as well, but the units used here do not limit the timeframe in which this document was written, as their use spans centuries. The main focus in the analysis of the Gofushimiin shinkan takimonohō is to show 1) a variance in time, as well as 2) defining economic thought as a marker of temporality.

25 The Mukusa no takimono 六種の董物, produced and enjoyed since the seventh century: baika 梅花 (plum blossom), kurobō 黒方 (black formula), jijū 侍従 (lord stewart), rakuyo 落葉 (falling leaves), kikka 菊花 (chrysanthemum flower), kayo 荷葉 (lotus leaf). baika is the fragrance related to spring, kayo to summer, kikka to autumn, rakuyō to winter, jijū to love and kurobō to fortunate events (Kōdō Bunka Kenkyūkai, 2015: 25). To further interpretation see the second example in paragraph 6. I'm not quite sure what you mean by the phrase that I highlighted. 
In the beginning of the text we find a commentary about the connection of incense to Buddhism - how incense is the companion of Buddhist gods, constantly present in the religious realm:

薰物は仏の御世菩薩聖衆の沈檀の匂ひよりはじまりて。から国にも是をまなびうつせ り。我国につたはりし事は。

(Go-Fushimi Tennō 1971, 19/562)

[The knowledge about] incense begins with the aloes- and sandalwood fragrance of the Buddhist gods, which was learned and imitated in ancient China too. [This knowledge] reached our country. ${ }^{26}$

In this beginning, fragrance connects the mythological past with the historical present. As the fragrance of the gods should be copied by incense, it serves as a medium not only permeating the air but also transcending time, chronographically reaching from a time that is absolute (what Harweg [2009, 2, 18] calls mythographic) and unconnected to the present of an observer into a time that is relational and historiographic with a continuous link to the present. (Also see Steineck 2018, 175-6). The concept of multitudinous lifespans to live through in Buddhist thought illustrates in a very concrete way cyclic time consciousness: circular in its movement, but not endlessly repetitive, going towards a destination. Incense and the knowledge about it are sacred and valuable, its value raised by the information about the way incense came to Japan. Buddhism and incense belong together, incense being indispensable

${ }^{26}$ The translations of these parts of the Gofushimiin shinkan takimonohō are my own. 
for religious action. Therefore, the value of incense is defined not only by supply (or its shortage) but also by its religious necessity.

A very different example in the same paragraph of the document connects each of the six kinds of fragrance to seasons:

春は梅花。むめの花の香に似たり。夏は荷葉。はすの花の香に通へり。秋は落葉。も みぢ散頃ほに出てまねくなるす〉きのよそほひも覚ゆなり。冬は菊花。きくのはなむ ら々々うつろふ色。露にかほり水にうつす香にことならず。小野宮殿実頼の御秘法に は長生久視のか香なりとしるされたり。黒方。冬ふかくさえたるに。あさからぬ気をふく めるにより。四季にわたりて身にしむ色のなづかしき匂ひかねたり。侍従。秋風蕭颯 たる夕。心にくきおりふしものあはれにて。

(Go-Fushimi Tennō 1971, 19/562)

Spring is baika. It is similar to the fragrance of plum blossom. Summer is kayō. It is like the fragrance of Indian lotus. Autumn is rakuyō. It calls forth the colors of autumn foliage and is evocative of the rustling pampas grass. Winter is kikka. The chrysanthemum is a flower with magnificently ephemeral colors, and it cannot be distinguished between fragrance wafting through morning dew and incense transferred by water. The secret recipe of Saneyori from Ono Palace lets us know of a scent of longevity: kurobō. In winter there is freezing chilliness, which inspires serious feelings. This fragrance seems to freeze the body while going through the seasons, and it serves as a fragrance of retrospection. Jiju is an evening of cooling love. The season is detestable, and sometimes it evokes an awareness of impermanence. 
Incense here is linked to seasons and feelings conjured by the thought of the flow of time. Two different interpretations are possible: one is the seasonality of consumption, a view conveyed by delimiting, implicit-material temporal expressions, exhibiting a practical, or prescriptive dimension of chronography. A different interpretation emphasizes the symbolic nature of the fragrance, expressed through the seasons. In this case, time expresses typological attributes of incense, thetically affirming the temporality of its characteristics. These interpretations are not exclusive, and they may both apply. The seasons also show cyclic time as markers of a year cycle, constantly repeating their succession. This passage further shows the duality of permanence and impermanence. Longevity is achieved by applying the right blend of fragrance, and the context here implies not only deceleration of aging but even stagnation by freezing, bordering on permanence. Knowledge about the impermanence of things however is expressed through the aesthetic concept of mono no aware 物の哀れ (awareness of impermanence).

Both examples are drawn from the descriptive commentary, and they display generally a more archaic worldview. The author mentions this explicitly in the following sentences:

今の世には其方思ひ々々なり。名ある程の方もさま々々なれども。[...]是皆時に随て 昔の人は知けれど。今の世にさらに聞えず。

(Go-Fushimi Tennō 1971, 19/562)

I am studying these formulas, even if there are many new formulae nowadays. [...]

These [the six fragrances] were well known by people of earlier times, but now they are unheard of. 
The author here refers to knowledge from at least a few centuries ago, also to be found in the Kunjū ruishō, a comprehensive document compiled in mid twelfth century. Even if many different ways of using incense have developed recently, the author feels nostalgic admiration towards the old ways and, ignoring the new incense manuals, feels drawn to the old recipes.

The examples above show expressions of the authors' perception of time in a personal and emotive syntax; the next examples are drawn from the prescriptive and practical instructions and formulae in the same text, devoid of emotion and typecasting an instructional text or recipe. The first example is concerned with the roasting of shells, an ingredient quite commonly used in almost all mixtures:

\section{凡三四日ばかり是を采り。但貝の体にしたがひて遅速ある也。是を折てこ〉ろみる に。おれやすくてそのくちき黄なり。是を持てそのご期とす。こがれぬれば尤不宜也。} (Go-Fushimi Tennō 1971, 19/563)

Roast them about 3 or 4 days but subject the tempo to the size of the shells. Try to break them when they are brittle, and the opening is getting yellow. Then the right amount of time has passed. It is really not advisable to apply amadura if the shells are burned.

On the quantitative level, the exemplary instruction here provides formal chronographic expressions: determined ("3 to 4 days long"), as well as undetermined ("as long as it takes the shells to become brittle") measurable. This is a common feature of the instructive part of the document, as it serves to temporally organize the sequence of steps. One could argue that the intuitive awareness of material changing irreversibly into different material by the use of fire may show signs of linear thinking. On the qualitative level, time here is assessed in an explicit 
way, and affirmed in its existence ("then the right amount of time has passed"), in a rare chronothetic expression to be found in such instructions. Time usually holds the function of organization and is recognized as something existing, but the pondering about time concepts is not a primary feature in texts like the Gofushimiin shinkan takimonohō.

The next example shows economic thinking and a consciousness about supply problems:

梅花。ぢん。八両。丁子。三両三分。せんかう。一分二朱。かい。三両。かんぞ。一 分。白だん。三分。ざかう。二分。くんろく。一分。 梅花のすくなくわかちたる定。 ぢん。二両二朱。[...]かんぞ。四分。

(Go-Fushimi Tennō 1971, 19/568)

Baika formula: aloeswood: 8 ryō; clove: 3 ryō 2 bu; lower quality aloeswood: 1 bu 2 shu; shell: 3 ryō; Chinese liquorice: $1 \mathrm{bu}$; sandalwood: $3 \mathrm{bu}$; musk: $2 \mathrm{bu}$; frankincense: $1 \mathrm{bu}$. This is the instruction in case you want to mix a small amount of baika incense: aloeswood: 2 ryō 2 shu [...] Chinese liquorice: 4 bu.

The sentence between the two recipes provides instructions on how to proceed if a consumer either does not have enough ingredients or does not want to produce too much of the same incense mixture. The next example explains how exactly one is supposed to behave if one ingredient is not available:

$$
\begin{aligned}
& \text { かえふのほう。かんぞ。二分。ぢん。三両二分。白だん。一分。かい。一両一分。しゆ } \\
& \text { くこん。一分。是はなはばかう子。一両一分。 }
\end{aligned}
$$


(Go-Fushimi Tennō 1971, 19/568)

Kayō formula: Chinese liquorice: $2 \mathrm{bu}$; aloeswood 3 ryō $2 \mathrm{bu}$; sandalwood: $1 \mathrm{bu}$; shell:

1 ryō $1 \mathrm{bu}$; shukukon: 1 bu (if you do not have shukukon, take musk); clove: 1 ryō 1 bu.

Here the added sentence is written in warich $\bar{u}$ 割注 (small script) in the original. This script type is used for notes and additions. The reasons for such additional information are manifold and may even lie in personal preferences, but in the context of an author believing these recipes to be the apex of incense-making and of long trading routes constantly influencing the availability of exotic ingredients, the insertions here rather give advice in how to react to shortages in times of need. Also, they nicely illustrate the authors' virtuosity in handling incense material.

The next example follows after the "mixing procedure," emphasizing the fact that the right way to mix the ingredients is to be followed without any deviation:

是秘伝也。急ぐ時かならずしもしからずといいり。

(Go-Fushimi Tennō 1971, 19/564)

This is a secret message. Under no circumstances undertake this if busy.

This sentence expresses concern regarding the time-consuming process of incense-making and warns the reader to attach enough importance to the impending tasks. Time is characterized as "busy," chronotypological information on the personal experience of time. Usually someone interested in such an exotic endeavor like incense contests must have been 
wealthy as well as powerful, with duties and responsibilities different than those of commoners. In this context, the warning makes much sense and displays awareness of the leaders' full schedules.

\section{Conclusion}

Inherent in a clock's function is a specific time concept, making it redundant or useful in certain areas of life. By examining three different types of clocks used in medieval Japan, I have differentiated several time concepts, not exclusive in their morphologies but still showing plural temporalities. The incense clock unites different time morphologies, only visible from the perspective of different symbolic forms: incense as an economic factor (economy) and incense as a temporal factor (religion). While the religious function mainly connects myth with history and the present, and cyclic time is prevalent, incense as a commodity in a trading network primarily necessitates a linear temporal organization. Time in economic systems is treated like a commodity itself, qualitatively homogenous and being at odds with other time concepts prevalent in society. The analysis of the incense instruction written or commissioned by Go-Fushimi Tennō repeatedly shows variance in time morphologies simultaneously existing in medieval Japan. Each of the three text types chosen for the partitioning of the text (commentary, formulae, instruction) not only displays content differences but also distinctive differences in their temporal structure. A temporal analysis therefore may be beneficial for the formulation of a not-yet-described text genre or type like the incense instruction, and it may be a subject of further research. 


\section{Acknowledgements}

This project has received funding from the European Research Council (ERC) under the European Union's Horizon 2020 research and innovation program (grant agreement No. 741166). I would like to thank my colleagues of the ERC grant project Time in Medieval Japan—Raji C. Steineck, Simone Müller, Daniela Tan, Kōhei Kataoka, Georg Blind, Alexandra Ciorciaro, and Etienne Stähelin, as well as Sebastian Balmes and Karl L. Zehnder-

- for their invaluable help towards the realization of this essay. Nonetheless, all mistakes and flaws are certainly mine. I also would like to thank the participants of the $17^{\text {th }}$ Triennial Conference of the ISST in 2019 for their insightful questions and input on my presentation, which encouraged me to submit this article in the first place. As it is not possible to enter the inner sanctum of Nigatsudō as a female researcher, I was grateful for the uncomplicated solution of the incense clock being brought to the south gate of the hall, where I was able to observe and photograph the unique treasure. My heartfelt thanks therefore go to the former abbot Kitakawara Kokei, as well as the present head of the hall, Ueno Shūshin, and his considerate staff. 


\section{References}

Amino, Yoshihiko. 2012. Rethinking Japanese History. Michigan Monograph Series in Japanese Studies, vol. 74. Ann Arbor: University of Michigan Center for Japanese Studies.

Ariga, Kōen 有賀要延. (1990) 1995. Kō to bukkyō 香と仏教. Second edition. Tokyo: Kokusho kankōkai.

Bedini, Silvio A. 1994. The Trail of Time: Time Measurement with Incense in East Asia: Shih-chien ti tsu-chi. Cambridge: Cambridge University Press.

Cassirer, Ernst. (1923) 2010. Philososphie der symbolischen Formen. 3 volumes. Hamburg: Felix Meiner Verlag.

Canales, Jimena. 2016. “Clock / Lived.” In Time: A Vocabulary of the Present, edited by Joel Burges and Amy J. Elias, 113-128. New York: New York University Press.

Dux, Günter. 1989. Die Zeit in der Geschichte: Ihre Entwicklungslogik vom Mythos zur Weltzeit: mit kulturvergleichenden Untersuchungen in Brasilien (J. Mensing), Indien (G. Dux/K. Kälbe/J. Messmer) und Deutschland (B. Kiesel). Frankfurt am Main: Suhrkamp.

Farris, William Wayne. 1998. “Trade, money, and merchants in Nara Japan.” Monumenta Nipponica 53 (3): 303-334.

Fujiwara, Norikane 藤原範兼. (1894) 1971. Kunjū ruishō 薰集類抄.In Gunsho ruijū 群書類 従, vol. 19, edited by Hanawa, Hokiichi 塙保已一, 525-561. Third edition. Tokyo: Zoku Gunsho ruijū Kanseikai. 
Go-Fushimi Tennō 後伏見天皇. (1894) 1971. Gofushimiin shinkan takimonohō 後伏見院宸 翰薰物.In: Gunsho ruijū 群書類従, vol. 19, edited by Hanawa, Hokiichi 塙保已一, 562-574. Third edition. Tokyo: Zoku Gunsho ruijū Kanseikai.

Griffiths, Jay. 2005. “Living time.” In About Time: Speed, Society People, and the Environment, edited by Tim Aldrich, Forum for the Future, 53-65. United Kingdom: Greenleaf Publishing Ltd.

Harweg, Roland. 2009. Zeit in Mythos und Geschichte: weltweite Untersuchungen zu mythographischer und historiographischer Chronographie vom Altertum bis zur Gegenwart. Berlin: Lit Verlag.

Hashimoto, Manpei 橋本万平. 1978. Nihon no jikoku seido 日本の時刻制度. Tokyo: Hanawa Shobō.

Hayakawa, Jinzō 早川甚三. 2007. Bungaku to kōdō 文学と香道. Nagoya: Arumu.

Horiike, Shunpō 堀池春峰. (1996) 2008. Tōdaiji Omizutori: nigatsudō shunie no kiroku to $k e n k y \bar{u}$ 東大寺お水取り：二月堂修二会の記録と研究. Second edition. Tokyo: Shōgakkan.

Iwasaki, Kae 岩㟝佳枝, Takahashi Kiichi, and Shiomura Kō. 1993. Shichijū ichiban shokunin utaawase. Shinsen kyōkashū. Kokon ikyokushū 七十一番職人歌合. 新撰狂 歌集. 古今夷曲集. Shin Nihon koten bungaku taikei 新日本古典文学大系, vol. 61 . Tokyo: Iwanami Shoten.

Jinbo, Hiroyuki 神保博行. (2003) 2004. Kōdō no rekishi jiten 香道の歴史事典. Second edition. Tokyo: Kashiwashobō.

Koch, Angelika. 2020, “Diplomatic Devices: The Social Lives of Foreign Timepieces in Late Sixteenth- and Early Seventeenth-Century Japan”. KronoScope 20, (1): 64-101. 
Kōdō bunka kenkyūkai 香道文化研究会. (1989) 2015. Kō to kōdō 香と香道. Fifth edition. Tokyo: Yuzankaku.

Maki, Yūsuke 真木悠介. (2003) 2017. Jikan no hikaku shakaigaku 時間の比較社会学. Twelfth edition. Tokyo: Iwanami Shoten.

Matsubara, Mutsumi 松原睦. 2012. Kō to bunkashi: nihon ni okeru jinkōjuyō no rekishi 香と 文化史：日本における沈香需要の歴史. Seikatsu bunkashi sensho 生活文化史選 書. Tokyo: Yuzankaku.

Minagawa, Masaki 皆川雅樹. 2014. Kodai ōken to tōbutsu kōeki 古代王権と唐物交易. Tokyo: Yoshikawa Kōbunkan.

Miyake, Kazuo 三宅和朗. 2010. Jikan no kodaishi: reiki no yoru, chitsujo no hiru 時間の古 代史 : 霊鬼の夜、秩序の昼. Tokyo: Yoshikawa Kōbunkan.

Nara National Museum 奈良国立博物館. 2016. Omizutori 㧍水取り: feature exhibition, treasures of Tōdaiji’s Omizutori ritual. Special line-up 特別陣列. Nara: Tenrijihōsha.

Satō, Michiko. 2009. Tōdaiji Omizutori: haru wo matsu inori to sange no hōe 東大寺扔水取 り：春を待つ祈りと懴悔の法会. Asahi sensho 朝日選書 852. Tokyo: Asahi Shinbun Shuppan.

Segal, Ethan Isaac. 2011. Coins, Trade, and the State: Economic Growth in Early Medieval Japan. Harvard East Asian Monographs, vol. 334. Cambridge (USA): Harvard University Asia Center.

Steger, Brigit and Steineck, Raji C. 2017. "Introduction from the Guest Editors to the Special Issue ‘Time in Historic Japan."” Kronoscope 17 (1):7-15. 
Steineck, Raji C. 2017. “Time in Old Japan: In Search of a Paradigm.” Kronoscope 17 (1): $16-36$.

Steineck, Raji C. 2018. "Chronographical Analysis: An Essay in Methodology.” Kronoscope, 18 (2): 171-198.

Tsutsui, Kanshō 筒井寛昭; Kajitani Ryōji 梶谷亮治; Bandō Toshihiko 坂東俊彦. (2010) 2018. Tödaiji no rekishi 東大寺の歴史. Motto shiritai もっと知りたい. Fifth edition. Tokyo: Kabushikigaisha Tokyo Bijutsu.

Zerubavel, Eviatar. 1976. "Timetables and Scheduling: On the Social Organization of Time." Sociological Inquiry 46 (2): 87-94. Wiley Online Library. 